Document downloaded from:

http://hdl.handle.net/10251/148182

This paper must be cited as:

Arcaro, S.; Moreno, B.; Chinarro, E.; Salvador Moya, MD.; Borrell Tomás, MA.; Nieto, M.; Moreno, R.... (2017). Properties of LZS/nanoAl2O3 glass-ceramic composites. Journal of Alloys and Compounds. 710:567-574. https://doi.org/10.1016/j.jallcom.2017.03.299

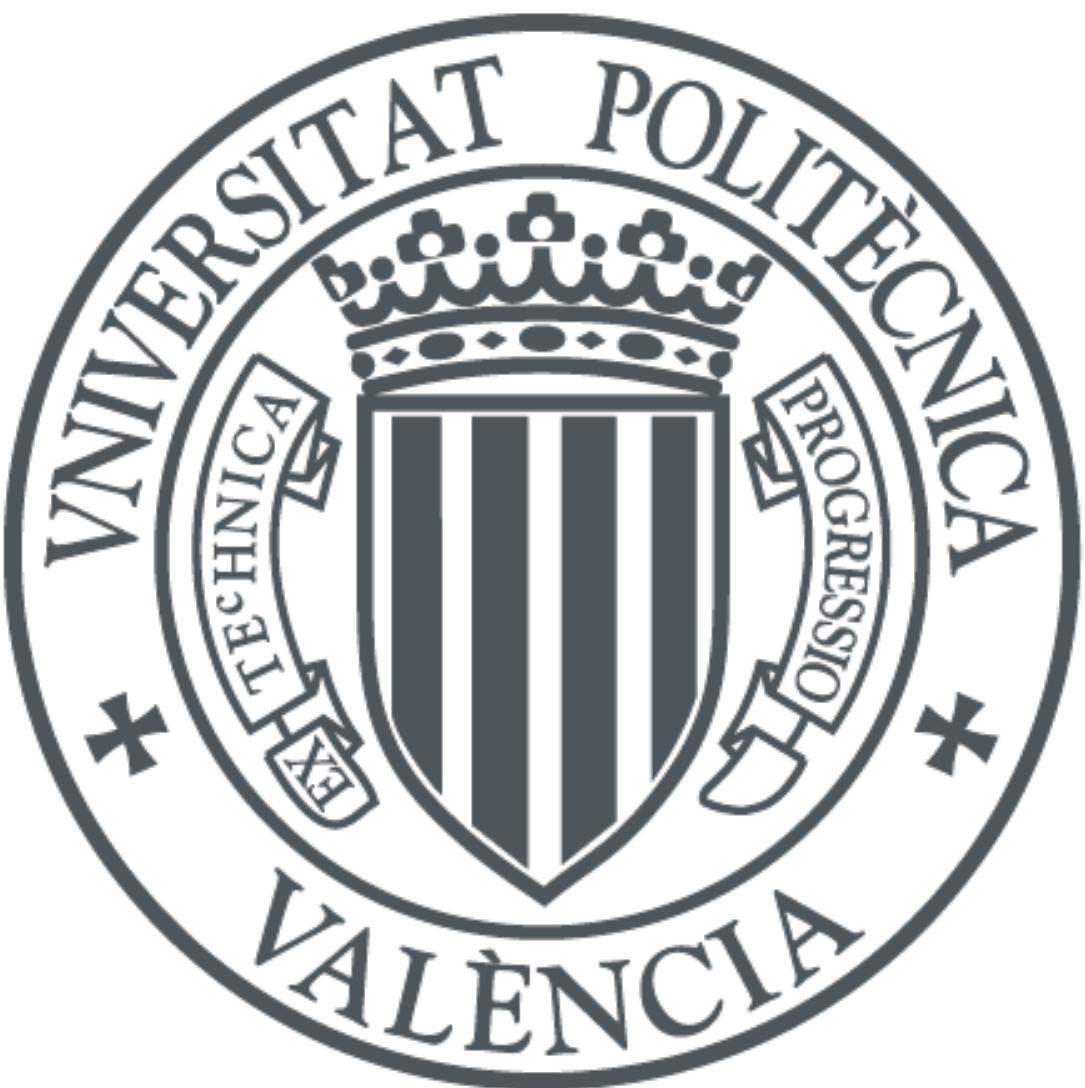

The final publication is available at

https://doi.org/10.1016/j.jallcom.2017.03.299

Copyright Elsevier

Additional Information 


\section{Properties of $\mathrm{LZS} /$ nano $\mathrm{Al}_{2} \mathrm{O}_{3}$ glass-ceramic composites}

S. Arcaro'; B. Moreno², E. Chinarro²; M.D. Salvador3; A. Borrell3; M.I. Nieto², R.

Moreno $^{2}$, A.P. Novaes de Oliveira ${ }^{1}$

Laboratory of Glass-Ceramic Materials (VITROCER) - Department of

Mechanical Engineering (EMC), Federal University of Santa Catarina (UFSC),

PO Box 476, 88040-900 Florianópolis (SC), Brazil'

Institute of Ceramics \& Glass, CSIC, Madrid, Spain²

Instituto de Tecnología de Materiales (ITM), Universitat Politècnica de València,

Camino de Vera s/n, 46022 Valencia, Spain ${ }^{3}$

\section{ABSTRACT}

The LZS glass-ceramic (19.58 $\left.\mathrm{Li}_{2} \mathrm{O} \cdot 11.10 \mathrm{ZrO}_{2} \cdot 69.32 \mathrm{SiO}_{2}\right)$ have a high coefficient thermal expansion (CTE) which can be a limitation in some applications. The addition of alumina in a LZS glass-ceramic matrix is able to reduce the CTE significantly. This happens because of the alumina affinity with respect to lithium silicates to form $\beta$-spodumene $\left(\mathrm{LiAlSi}_{2} \mathrm{O}_{6}\right)$, a crystalline phase having a CTE nearly zero $\left(0.9 \times 10^{-6}{ }^{\circ} \mathrm{C}^{-1}\right)$. In this work, (1-5 vol.\%) $\mathrm{Al}_{2} \mathrm{O}_{3}$ nanoparticles $(13 \mathrm{~nm})$ were added to a $L Z S(3.5 \mu \mathrm{m})$ glass-ceramic matrix to prepare composites with the main goal of evaluation the influence of $\mathrm{Al}_{2} \mathrm{O}_{3}$ on their mechanical, thermal and electrical properties. Each composition was wet homogenized and then dried at $110 \mathrm{C}$ for $48 \mathrm{~h}$ for disaggregation. The composites, sintered at $900{ }^{\circ} \mathrm{C}$ for 30 min, with relative densities between $92 \%$ and $98 \%$, showed zircon and $\beta$-spodumene as main crystalline phases. The incorporation of increasing additions of nanosized alumina progressively decreases the final density. This makes the properties to slightly decrease, also. The Young's modulus significantly decreases from 111 to $78 \mathrm{GPa}$ of hardness due to the exponential variation with porosity, but the changes of toughness and hardness are much lower. The electrical conductivity was maintained within \pm 10-7 S.cm-1, and the dielectric constant ranged from 5 and 6 for all compositions. Thermal conductivity ranged around 4.2 to $3.5 \mathrm{~W} / \mathrm{mK}$.

Keywords: Composites; Nanoalumina; Glass-ceramics; Properties. 


\section{Introduction}

The constant advances in the industry are originated from the need to develop solutions for the most varied applications. Clearly, in the last 20 years, the emergence of highly complex structures derived from the combination of several classes of materials. Many efforts have been devoted to improve the mechanical, thermal, electrical and chemical behavior of ceramic materials, exploiting different strategies, such as the study of new compositions, use of reinforcements with particles, fibers, and the use of nanometric secondary phases for ceramic matrix composites and nanocomposites [1-5]. The demand of more efficient materials for different applications has stimulated the search of new compounds having low thermal expansion, since the behavior of the materials at different temperatures is crucial in many applications. Therefore, compounds with low coefficient of thermal expansion (CTE) are of great interest [6-8]. In fact, the material's thermal shock resistance is mainly related with a low CTE, among other secondary properties, since brittle materials are more susceptible to fracture as a result of non-uniform dimensional changes.

Materials that have low CTE are being developed for applications requiring rapid temperature changes such as heat exchangers, ceramics for use in household cookers, high performance cutting tools and precision optical instruments as well as burner nozzles. Furthermore, in applications involving the joining of materials, the thermal expansion requires a fairly narrow compatibility to match the shrinkage, as in glass and glass-ceramic/metal systems for hermetic seals, laser tubes, electronic devices for measuring and monitoring, sealants for solid oxide fuel cells (SOFCs), and substrates used in 
microelectronic packaging on LTCC technology (low temperature co-fired ceramics) [9-18].

Glass-ceramics can be a solution in many applications due to their good mechanical, chemical, and abrasion resistance, high hardness, variable thermal expansion according to chemical composition, and their sinterability to relatively high densities (92-98\%) at temperatures usually lower than $1000{ }^{\circ}$. The characteristics and properties of glass-ceramic materials depend primarily on their intrinsic properties as well as on the size, volumetric fraction and morphology of the formed crystals. Moreover, the properties of glass-ceramic materials depend also on the properties of the residual amorphous phase and the residual porosity (in case of sintered glass-ceramics). The crystalline phase responsible for the final properties of a glass-ceramic material, for example the coefficient of thermal expansion (CTE), is controlled by the chemical composition of the parent glass and the applied thermal cycle [19, 20]. Thus, an unlimited number of glass-ceramic materials can be prepared by conventional processes of manufacture of ceramic materials since the most used technology of producing glass-ceramic consists in sintering and crystallization of a powder (parent glass) compact. The LZS $\left(\mathrm{Li}_{2} \mathrm{O}-\mathrm{ZrO}_{2}-\mathrm{SiO}_{2}\right)$ glass-ceramic system has been investigated since 1996 [21] due to its interesting properties, such as relatively high mechanical strength and hardness and relatively high resistance to abrasion wear and chemical attack. In fact, relatively recent $[22,23]$ studies have demonstrated that LZS glass-ceramics containing lithium and zirconium silicates $\left(\mathrm{Li}_{2} \mathrm{Si}_{2} \mathrm{O}_{5}\right.$ and $\left.\mathrm{ZrSiO}_{4}\right)$ as main crystalline phases achieved hardness values of $8 \pm 0.5 \mathrm{GPa}$, bending strength of $190 \pm 13 \mathrm{MPa}$, and fracture toughness of $3.65 \pm 0.20 \mathrm{MPa} \cdot \mathrm{m}^{1 / 2}$. However, a limitation in some applications 
is concerned to the relatively high coefficients of thermal expansion, CTE (8.8$10 \times 10^{-6} \mathrm{C}^{-1}$ ) of the obtained LZS glass-ceramics. The production of such glass-ceramics with their inherent properties but with lower CTE is of practical interest. In fact, some studies [24-29] have been conducted in order to determine the influence of alumina additions in a LZS glass-ceramic matrix, particularly with the purpose of reducing the CTE.

In previous work $[30,31]$ it was demonstrated that the addition of nanosized alumina in a LZS glass-ceramic matrix was able to reduce the CTE significantly. This happens because of the alumina affinity with respect to lithium silicates to form $\beta$-spodumene $\left(\mathrm{LiAlSi}_{2} \mathrm{O}_{6}\right)$, a crystalline phase having a CTE nearly zero $\left(0.9 \times 10^{-6} \mathrm{C}^{-1}\right)$. In this case, the CTE changed from $9.5 \times 10^{-6} \mathrm{C}^{-1}$ for the LZS glass-ceramic to $4.4 \times 10^{-6}{ }^{\circ} \mathrm{C}^{-1}$ for a 5 vol.\% nanoparticles of alumina LZS glass-ceramic matrix composite.

It is important to remark the extraordinary application potential of these glass-ceramic composites. In this way, the investigation of the behavioral properties of these materials in addition to their CTE control reported elsewhere $[30,31]$, has become necessary facing their future applications. Accordingly, the main objective of this paper was to investigate the mechanical and electrical properties of those composites, which have not been reported before. The most important aim is the possibility to prepare a new family of glass-ceramics with tailored CTE through the addition of nanoparticles with similar properties than other commercially employed LTCC systems. 


\section{Experimental procedure}

In this work the following raw materials were used: a LZS glass (parent glass powder) with an average particle size $d_{v .50}=3.5 \mu \mathrm{m}$, composition $19.58 \mathrm{Li}_{2} \mathrm{O} \cdot 11.10 \mathrm{ZrO}_{2} \cdot 69.32 \mathrm{SiO}_{2},(\mathrm{~mol} \%)$, and a commercially available $\mathrm{Al}_{2} \mathrm{O}_{3}$ nanopowder (Aeroxide® AluC, Evonik-Degussa, Germany) with an average particle size $d_{v .50}=13 \mathrm{~nm}$, a specific surface area of $100 \mathrm{~m}^{2} / \mathrm{g}$ and made up of a mixture of $\delta / \gamma$-alumina phase.

Batches to produce the parent glass were prepared from well-mixed powders containing appropriate amounts of $\mathrm{Li}_{2} \mathrm{CO}_{3}, \mathrm{ZrSiO}_{4}$, and quartz $\left(\mathrm{SiO}_{2}\right)$ as raw materials. Subsequently, each batch was placed in a Pt crucible $\left(100 \mathrm{~mL}\right.$ ) and melted at $1550{ }^{\circ} \mathrm{C}$ for $2 \mathrm{~h}$ in an electr ically heated furnace (Jung, LF0917, Brazil). The melts were cast into deionized water to provide frits for milling. The resulting glass frit was milled according to a two-step procedure consisting on a dry milling stage followed by a long wet milling step down to an average particle size $d_{v \cdot 50}=3.5 \mu \mathrm{m}$ and surface area $2.45 \mathrm{~m}^{2} / \mathrm{g}$. Details of the milling procedure and particle measurements are available in reference [31].

The chemical composition of the milled powder (LZS parent glass) was determined by X-ray fluorescence (Philips, PW 2400, The Netherlands) and atomic absorption spectroscopy (Unican, 969, United Kingdom). Further details on the preparation and processing of the LZS frit are reported in a previous work [31].

The differently prepared compositions were labeled as LZS, $1 \mathrm{An}, 2.5 \mathrm{An}$, and $5 \mathrm{An}$, for contents of nanosized alumina of $0,1,2.5$, and 5 vol.\%. Each composition was wet homogenized (using a water to powder weight ratio of 
60/40) on a propeller mechanical agitator (IKA RW Digital 200, Germany). Subsequently, the suspensions of the homogenized powders were dried at $110^{\circ} \mathrm{C}$ for $48 \mathrm{~h}$ and then disaggregated into a fast laboratory ball mill (SERVITECH, CT-242, Brazil) for 15 min. Thus, samples of each composition were uniaxially pressed in a cylindrical steel die by means of a hydraulic press (ST Bovenau P10, Brazil) at $100 \mathrm{MPa}$. The obtained powder compact samples (Due to the requirements of each equipment, for each of the measured properties, it was necessary to have a sample size) were dried at $110^{\circ} \mathrm{C}$ for 2 h. In a subsequent step, the dried samples were fired (for sintering and crystallization) at $900^{\circ} \mathrm{C}$ for 30 min with a heatin g rate of $10 \mathrm{C} / \mathrm{min}$ and cooled to room temperature, as stated in an earlier work for the LZS parent glass [31].

The linear shrinkage was measured along the diameter of the samples (disks with $10 \mathrm{~mm}$ in diameter and $6 \mathrm{~mm}$ thick). The true densities $\left(\rho_{t}\right)$ of powdered samples were determined by using a helium pycnometer (AccuPyc 1340, Micromeritics, USA). The apparent densities $\left(\rho_{a}\right)$ of fired samples were determined by relating their geometrical measurements, obtained using a caliper (Mitutoyo, Japan, accuracy $\pm 0.01 \mathrm{~mm}$ ), and their masses (Shimadzu AX200, Japan, at $0.001 \mathrm{~g})$. The relative densities $\left(\rho_{r}\right)$ were determined relating the apparent densities and the true densities of the samples according to Equation 1.

$$
\rho_{r}=\left(\rho_{a} / \rho_{t}\right) \times 100
$$

To determine the evolution of crystalline phases in all studied samples, $\mathrm{X}$ ray diffraction was performed using a powder XRD (Philips, model X'Pert, The Netherlands) diffractometer using Ni-filtered Cu-Ka radiation $(1.5418 \AA)$ at $40 \mathrm{kV}$ and $30 \mathrm{~mA}$. Samples were rotated to minimize the effect of preferential 
orientation and analyzed in powder form with particle size smaller than $45 \mu \mathrm{m}$, using a step size of 0.02 , dwell time of $2 \mathrm{~s}$ per step and $2 \theta$ between 5 and $80^{\circ}$ $2 \theta$ angle range. JCPDS data banks were used for identification of the resulting crystalline phases. The quantitative analysis of the crystalline phases has been performed by the Rietveld method [32-34]. The refinement of the X-ray patterns as well as the simulation and quantification of the crystalline phases were performed by the X'Pert HighScore Plus $\AA$ software (Philips, The Netherlands).

The microstructure of the fired samples was observed on fracture surfaces using a field emission gun scanning electron microscope (FE-SEM, S4800 type I, Hitachi, Japan).

The thermal conductivity of the composites was determined using a Tci Thermal Conductivity analyzer (C-THERM TECHNOLOGIES) of the composites (disks with $30 \mathrm{~mm}$ in diameter and $5 \mathrm{~mm}$ thick)

Hardness was evaluated by micro and nanoindentation techniques. Fracture toughness $\left(\mathrm{K}_{\mathrm{IC}}\right)$ values were calculated by measuring the cracks induced by applying a load of $2 \mathrm{~kg}$ for $10 \mathrm{~s}$ with an image analysis program and utilizing the equation proposed by Niihara et al. [35]. For each sample 10 hardness measurement were performed. Hardness $(\mathrm{H})$ and Young's modulus (E) were measured by a nanoindenter G-200 of Agilent Technol. (Inc., Santa Clara, CA) under a $2000 \mathrm{~nm}$ constant indentation depth program. A Berkovich tip was used after calibration of the function area in fused silica. Stiffness was recorded in depth by Continuous Stiffness Measurement (CSM). The oscillation amplitude was programmed to $2 \mathrm{~nm}$ with a frequency of $45 \mathrm{~Hz}$.

Two-point probe electrical conductivity measurements were performed for the composites (disks with $6.5 \mathrm{~mm}$ in diameter and $0.3 \mathrm{~mm}$ thick). The 
electrical contact was made by sandwiching the disk shaped samples with $\mathrm{Pt}$ foils using coils to ensure good contacts. The sandwiched sample was inserted into the oven and the electrical resistance was measured in the range of $300-900{ }^{\circ} \mathrm{C}$ in air atmosphere by impedance measureme nts in the range of 1 $\mathrm{MHz}-10 \mathrm{~Hz}$ (Agilent 4294A) with amplitude of $50 \mathrm{mV}$. It is noteworthy that for temperatures below $300{ }^{\circ} \mathrm{C}$ it has not been possible to obtain the impedance curve with precision, because the electrical conductivity is very low in relation to the effects of the electrode.

The acquired impedance spectra were analyzed using the ZVIEW® fitting software. The activation energy and electrical conductivity at room temperature were obtained from an Arrhenius plot [36]. According to the Arrhenius conductivity equation the relation between conductivity in solids and the temperature $\mathrm{T}$ is given by Equation (2):

$$
\sigma=\sigma_{0} \exp \left(-\frac{E Q}{k V}\right)
$$

where Ea is the activation energy for the electrical conduction processes [36].

Dielectric constant and dielectric loss tangent $(\tan \delta)$ measurements were performed for the composites (discs with $25 \mathrm{~mm}$ in diameter and $2 \mathrm{~mm}$ thick) with an equipment LCR E4980A (Keysight) using the Test Specific Fixture for dielectric constant measurement 16451B (Keysight) in frequency of $1 \mathrm{MHz}$ at room temperature.

The operating principle of the tests is based on the application of the sample as a capacitor in a closed circuit, where the capacitance is measured and the dissipation factor of the sample under a given tension. Due to the geometry of the electrodes and the sample, it is possible to calculate the dielectric constant according to Equation 3: 


$$
\varepsilon_{r}=\frac{C_{p} \cdot d}{(\pi \cdot D)^{2}} \cdot \varepsilon_{0}
$$

where $\varepsilon_{\mathrm{r}}$ is the dielectric constant of the material, $\varepsilon_{0}$ is the dielectric constant (in this case air: $\left.8.85410^{-12} \mathrm{~A} \mathrm{~s} / \mathrm{Vm}\right), \mathrm{C}$ is the equivalent parallel capacitance; $d$ is the sample thickness, and $D$ is the diameter of the inner electrode.

\section{Results and Discussion}

Table 1 shows the theoretical chemical composition and the experimental values obtained by chemical analysis of the LZS parent glass powder. As can be seen, there is a small difference between the theoretical and the measured elemental analysis of the LZS parent glass powder. In fact, there is a small decrease in the percentage related to the lithium oxide, probably due to some evaporation of $\mathrm{Li}$ during melting. The detection of aluminum oxide can be associated to the contamination produced by the wear of the alumina balls used for milling. In spite of this alumina contamination it, apparently, did not affect the expected performance of the obtained LZS glass-ceramics.

Table 2 shows the relative density and linear shrinkage for the LZS glassceramic samples (without $\mathrm{Al}_{2} \mathrm{O}_{3}$ ) and for the $\mathrm{LZS} /$ nano $\mathrm{Al}_{2} \mathrm{O}_{3}$ composites containing $1,2.5$ and 5 vol.\% of nanosized $\mathrm{Al}_{2} \mathrm{O}_{3}$ fired at $900 \stackrel{\circ}{\circ} \mathrm{C}$ for 30 min. It can be seen that the relative densities of the samples are situated between 92 and $\sim 98 \%$ while the linear shrinkage ranged from 12 to $15 \%$. The relative density of the LZS glass-ceramic is about $98 \%$. Moreover, it can be realized that the relative density of the composites decreases with increasing amount of added alumina, but does not change very much from a composition to another. 
This can be explained due to the presence of nanosized refractory alumina which is more reactive, reducing the viscous flow during sintering step.

Figure 1 shows SEM micrographs of fracture surfaces of the LZS glassceramic samples (without $\mathrm{Al}_{2} \mathrm{O}_{3}$ ) (a) and the composites containing 1 (b), 2.5 (c) and 5 vol.\% (d) of nanosized $\mathrm{Al}_{2} \mathrm{O}_{3}$ fired at $900 \stackrel{\circ}{\circ} \mathrm{C}$ for $30 \mathrm{~min}$. The analysis of the microstructures confirmed the observed variation of the relative density with firing temperature, i.e., the porosity increased as the alumina content increases from 1 to 5 vol.\%. However, it must be noted that the pore size decreases with increasing amount of alumina added to the LZS glass-ceramic materials. This fact can be related to the fact that the densification degree is slightly lower in the composites and hence the grain size is lower and also the pore size.

Figure 2 shows the obtained X-ray diffraction patterns of the LZS glassceramic samples (without $\mathrm{Al}_{2} \mathrm{O}_{3}$ ) and the composites containing 1,2.5 and 5 vol. $\%$ of nanosized $\mathrm{Al}_{2} \mathrm{O}_{3}$ fired at $900 \stackrel{\circ}{\circ}$ for 30 min. It was verified from the data collected from the XRD patterns related to the LZS glass-ceramic that zirconium silicate, $\mathrm{ZrSiO}_{4}$ (ICSD 100248), lithium disilicate, $\mathrm{Li}_{2} \mathrm{Si}_{2} \mathrm{O}_{5}$ (ICSD 15414) and $\beta$ quartz (ICSD 64980) are the crystalline phases formed. It is observed also that the addition of $\mathrm{Al}_{2} \mathrm{O}_{3}$ promotes the formation of $\beta$-spodumene, $\mathrm{LiAlSi}_{2} \mathrm{O}_{6}$ (ICSD 14235) and lithium metasilicate, $\mathrm{Li}_{2} \mathrm{SiO}_{3}$ (ICSD 28192) phases.

Table 3 shows the relative amounts of crystalline phases determined by Rietveld refinement of the LZS glass-ceramic samples (without $\mathrm{Al}_{2} \mathrm{O}_{3}$ ) and of the $\mathrm{LZS} /$ nanoAl $\mathrm{O}_{3}$ composites containing $1,2.5$ and 5 vol.\% of nanosized $\mathrm{Al}_{2} \mathrm{O}_{3}$ fired at $900{ }^{\circ} \mathrm{C}$ for $30 \mathrm{~min}$. It can be noticed that the LZS glass-ceramic has $34.8 \%$ of zirconium silicate, $44.5 \%$ of lithium disilicate and $20.7 \%$ of $\beta$ - 
quartz. Note that when adding alumina in the LZS glass-ceramic composition, there is a gradual decrease of lithium disilicate and the formation of $\beta$ spodumene phase so that lithium metasilicate formation is promoted. This is due to the presence of alumina, which has high affinity for lithium and they easily react to form $\beta$-spodumene. Since the molar ratio between alumina and lithium is not stoichiometric the $\beta$-spodumene phase is accomplished by the formation of lithium disilicate and lithium metasilicate. For the composition containing only 1 vol.\% of $\mathrm{Al}_{2} \mathrm{O}_{3}$, the formation of $\beta$-spodumene determinated by Rietveld method to occur to an extent of $13.9 \%$. For compositions containing 2.5 and 5 vol.\% nano alumina, the determined $\beta$-spodumene contents are 19.2 and $25 \%$. This crystalline phase is very interesting from the point of view of properties that can enhance the glass-ceramic behavior, mainly due to its low coefficient of thermal expansion. No crystalline phases based on alumina could be detected by XRD.

Figure 3 shows an example of Nyquist diagram obtained for LZS glassceramic sample heated at $500{ }^{\circ} \mathrm{C}$. In this diagram it can be observed a single semicircle. Each experimental point represents a measure of frequency, whose value increases from right to left. The results obtained for the other samples showed a similar behavior and consequently, they are not presented for sake of simplicity.

Getting the electrical resistance $\left(Z^{\prime}=R\right.$ when $Z^{\prime}=0$ in the impedance diagram, the side of low frequencies), with the aid of $z$ view software an Arrhenius plot (Figure 4) can be drawn from which the activation energy for the conduction process can be calculated. 
In all samples (glass-ceramic and composites), the electrical conductivity increases with temperature from values around $10^{-7} \mathrm{~S} / \mathrm{m}$ at $300{ }^{\circ} \mathrm{C}$ to values around $10^{-2} \mathrm{~S} / \mathrm{m}$ at $900{ }^{\circ} \mathrm{C}$, as it could be expected. In general, the Arrhenius plots indicate that for the whole temperature range tested the electrical conductivity remains higher with the addition of alumina. This fact is in opposition to the expected behaviour, since alumina is an insulating material. Observing the values measured at low temperatures, in this case $300^{\circ} \mathrm{C}$, the electrical conductivity obtained is about 7 orders of magnitude below that expected for alumina and silica, for example $\left(\sigma \mathrm{SiO}_{2}\right.$ and $\left.\mathrm{Al}_{2} \mathrm{O}_{3}=10^{-14} \mathrm{~S} . \mathrm{cm}^{-1}\right)$.

The conduction process of these materials is heavily influenced by the concentration of $\mathrm{Li}$ ions that have high mobility, exhibiting ionic conductivities as reported in the literature [37-40].

The activation energy for all cases decreased with increasing addition of alumina. This fact is probably related to the presence of increasing contents of $\beta$-spodumene phase with larger additions of alumina. Other authors have reported that glass-ceramics containing this phase have electrical conductivity values in the same range $[38,39]$.

The results of dielectric constant $(\varepsilon)$ and loss tangent $(\tan \delta)$ measured at $1 \mathrm{MHz}$ for the LZS glass-ceramic samples (without $\mathrm{Al}_{2} \mathrm{O}_{3}$ ) and for the LZS/nanoAl $\mathrm{O}_{3}$ composites containing $1,2.5$ and 5 vol.\% of nanosized $\mathrm{Al}_{2} \mathrm{O}_{3}$ fired at $900{ }^{\circ} \mathrm{C}$ for $30 \mathrm{~min}$ are presented in Table 4. The addition of $\mathrm{Al}_{2} \mathrm{O}_{3}$ to the LZS glass-ceramic matrix did not significantly change the dielectric constant.

The factors that can influence the dielectric constant results of glassceramic materials are, in addition to the content and type of crystalline phases, the presence of particles, the distribution of crystalline phases, grain size and 
porosity [32]. In this case, it can be said that the increase of $\varepsilon$ with the increment of $\mathrm{Al}_{2} \mathrm{O}_{3}$ may be related to a higher crystallization of $\beta$-spodumene phase that significantly increases with increasing alumina content according to Table 3. Studies performed with similar systems such as for LZSA glass-ceramics, reported $\varepsilon$ values from 8.39 to 8.61 [25]. The increase of the loss tangent can be related to the fact that porosity of samples increases with the amount of added alumina.

Adequate dielectric constant and low loss tangent values are required for substrates employed in the electronic industry. Comparing the obtained results in this study with those of commercial LTCC systems, for the LZS glass-ceramic samples and $\mathrm{LZS} /$ nano $\mathrm{Al}_{2} \mathrm{O}_{3}$ composites, it is possible to verify that they are comparable to, for instance, the commercial systems produced by Kyocera and Murata [41], according to Table 5.

Figure 5 shows the values of thermal conductivity for the LZS glassceramic samples (without $\mathrm{Al}_{2} \mathrm{O}_{3}$ ) and for the $\mathrm{LZS} /$ nano $\mathrm{Al}_{2} \mathrm{O}_{3}$ composites containing 1, 2.5 and 5 vol.\% of nanosized $\mathrm{Al}_{2} \mathrm{O}_{3}$ fired at $900 \stackrel{\circ}{\circ} \mathrm{C}$ for 30 min. It can be seen that the thermal conductivity decreases with increasing amount of added alumina, ranging from 4.17 to $2.88 \mathrm{~W} / \mathrm{mK}$. This decrease in thermal conductivity can be attributed to the increasing formation of the crystalline fraction of $\beta$-spodumene phase which has a reported thermal conductivity of 2 $\mathrm{W} / \mathrm{mK}$. The alumina present in the composite reacts to form spodumene regardless its particle size. Consequently the thermal conductivity of the nanocomposites is similar to that of the corresponding submicronic counterparts. It is important to mention the negative influence of porosity on thermal conductivity. In this case, the porosity increases with increasing $\mathrm{Al}_{2} \mathrm{O}_{3}$ 
additions from 2 to $8 \%$. Pores may be considered a low thermal conductivity phase dispersed in the structure since they are filled with air which is poor conductor of heat.

Figure 6 shows the values of Vickers microhardness for the LZS glassceramic samples (without $\mathrm{Al}_{2} \mathrm{O}_{3}$ ) and for the $\mathrm{LZS} /$ nanoAl $\mathrm{O}_{3}$ composites containing $1,2.5$ and 5 vol.\% of nanosized $\mathrm{Al}_{2} \mathrm{O}_{3}$ fired at $900{ }^{\circ} \mathrm{C}$ for 30 min. It can be seen that good results were obtained, i.e., Vickers hardness values ranged from 4.6 to $6.0 \mathrm{GPa}$. These relatively high values can be associated with the presence of zirconium silicate crystals which have a hardness between 9 and $10 \mathrm{GPa}$ [42]. Furthermore, it is possible to observe that there was a slight decrease in Vickers microhardness values with the addition of $\mathrm{Al}_{2} \mathrm{O}_{3}$, although this fact can be explained considering the increase of porosity and the amount of the $\beta$-spodumene crystalline phase which has a hardness value lower than that of zircon $[43,44]$.

Figure 7 shows the values Young's modulus (E) for the LZS glass-ceramic samples (without $\mathrm{Al}_{2} \mathrm{O}_{3}$ ) and for the $\mathrm{LZS} /$ nanoAl $\mathrm{O}_{3}$ composites containing 1 , 2.5 and 5 vol. \% of nanosized $\mathrm{Al}_{2} \mathrm{O}_{3}$ fired at $900{ }^{\circ} \mathrm{C}$ for $30 \mathrm{~min}$. As well as the microhardness values did not have a very large fluctuation even if a slight decrease of $E$ with increasing amount of added alumina ranging from $111 \mathrm{GPa}$ to $78 \mathrm{GPa}$ for the LZS composition with 5 vol. $\% \mathrm{Al}_{2} \mathrm{O}_{3}$ is observed. This fact could be associated mainly with the increased porosity with the addition of alumina since it is well known that the Young's modulus decreases exponentially with the porosity.

Figure 8 shows the values of fracture toughness $\left(\mathrm{K}_{\mathrm{IC}}\right)$ for the LZS glassceramic samples (without $\mathrm{Al}_{2} \mathrm{O}_{3}$ ) and for the $\mathrm{LZS} /$ nano $\mathrm{Al}_{2} \mathrm{O}_{3}$ composites 
containing $1,2.5$ and 5 vol. $\%$ of nanosized $\mathrm{Al}_{2} \mathrm{O}_{3}$ fired at $900 \stackrel{\circ}{\circ} \mathrm{C}$ for $30 \mathrm{~min}$. The $\mathrm{K}_{\mathrm{IC}}$ of glasses ranges from 0.6 to $0.9 \mathrm{MPa} \cdot \mathrm{m}^{1 / 2}$, while the glass-ceramic materials may reach values of up to $3.0 \mathrm{MPa} \cdot \mathrm{m}^{1 / 2}[45,46]$. In fact, $\mathrm{K}_{\mathrm{IC}}$ values for the different compositions maintain similar values, around $2.5 \mathrm{MPa} \cdot \mathrm{m}^{1 / 2}$. Previously reported work [23] demonstrates that LZS glass-ceramics fired at $800{ }^{\circ}$, where there is a greater amount of residual amorphous phase (glass), led to lower fracture toughness values than those fired (sintering and crystallization) at higher temperatures $(850,900,950 \stackrel{\circ}{\circ})$, where the residual amorphous phase content is lower. In terms of fracture toughness, it is worth noting that these LZS glass-ceramic materials exhibit a good behavior similar to that of alumina having fracture toughness of (between 2.8 and $4.5 \mathrm{MPa} \cdot \mathrm{m}^{1 / 2}$ ) but lower than zirconia stabilized with $3 \%$ yttrium oxide which has values ranging between 4.0 and $6.0 \mathrm{MPa} \cdot \mathrm{m}^{1 / 2}[47]$.

Flexural strength measurements were not performed in this work but they were done for similar composites prepared with submicron-sized alumina. The best results were obtained for samples with $1 \% \mathrm{Al}_{2} \mathrm{O}_{3}$ which achieved values of $290 \pm 20 \mathrm{MPa}$, similar to that of the LZS glass-ceramic without added alumina. The addition of alumina increases the porosity of the processed materials and thus, the flexural strength decreases. In the light of the other properties described above, i.e. Young's modulus, hardness and toughness, it can be expected that the flexural strength of the nanocomposites should be similar to that reported for the composites prepared with submicron sized alumina.

\section{Conclusions}


$19.58 \mathrm{Li}_{2} \mathrm{O} \cdot 11.10 \mathrm{ZrO}_{2} \cdot 69.32 \mathrm{SiO}_{2}$ (LZS) glass-ceramics and $\mathrm{LZS}+\mathrm{Al}_{2} \mathrm{O}_{3}$ composites containing $1,2.5$, and 5 vol.\% of nanosized $\mathrm{Al}_{2} \mathrm{O}_{3}$ fired (sintering and crystallization) at $900{ }^{\circ} \mathrm{C}$ for 30 min were successfully obtained and characterized. The obtained materials had relative densities between 92 and $98 \%$ and showed zirconium silicate and $\beta$-spodumene as the main formed crystalline phases. The nanocomposites obtained in this work had mechanical properties comparable to the composites prepared with submicron sized alumina reported elsewhere. This means that it is possible to tailor LZS based nanocomposites with similar behavioral properties than the corresponding submicronic counterparts. The incorporation of increasing additions of nanosized alumina progressively decreases the final density. This makes the properties to slightly decrease, also. The Young's modulus significantly decreases from 111 to $78 \mathrm{GPa}$ of hardness due to the exponential variation with porosity, but the changes of toughness and hardness are much lower. The electrical conductivity was maintained within $\pm 10^{-7} \mathrm{~S} \cdot \mathrm{cm}^{-1}$, and the dielectric constant ranged from 5 and 6 for all compositions. Thermal conductivity ranged around 4.2 to $3.5 \mathrm{~W} / \mathrm{mK}$.

\section{Acknowledgments}

This work has been supported by CAPES in the frame of the International Cooperation Program Science without Borders for Special Visiting Researcher PVE (MEC/MCTI/CAPES/CNPq/FAPs/№71/2013), Project № A011/2013 (Brazil) and CNPq (National Council for Scientific and Technological Development, Brazil). This work has been also supported by Ministerio de Economía y Competitividad (MINECO) and FEDER Funds under grant № MAT2016-67586-C3-R and grant ENE2013-49111-C2-1-R. A. Borrell 
acknowledges the MINECO for her Juan de la Cierva-Incorporación contract (IJCl-2014-19839).

\section{References}

[1] V.P. Rajan, F.W. Zok, Matrix cracking of fiber-reinforced ceramic composites in shear, J. Mechan. Solids, 73 (2014) 3-21.

[2] J. Wei, G. Pećanac, J. Malzbender, Mechanical behavior of silver reinforced glass-ceramic sealants for solid oxide fuel cells, Ceram. Int., 41 (2015) 1512215127.

[3] S. Widjaja, Determination of creep-induced residual stress in fiber-reinforced glass-ceramic matrix composites by X-ray diffraction, Mater. Charact., 47 (2001) 47-54.

[4] P.H.C. Camargo, K.G. Satyanarayana, F. Wypych, Nanocomposites: synthesis, structure, properties and new application opportunities, Mater. Res., 12 (2009) 1-39.

[5] L. Xia, F. Jin, T. Zhang, X. Hu, S. Wu, G. Wen, Enhanced oxidation resistance of carbon fiber reinforced lithium aluminosilicate composites by boron doping, Corro. Sci., 99 (2015) 240-248.

[6] X. Song, Z. Sun, Q. Huang, M. Rettenmayr, X. Liu, M. Seyring, G. Li, G. Rao, F. Yin, Adjustable Zero Thermal Expansion in Antiperovskite Manganese Nitride, Adv. Mater., 23 (2011) 4690-4694.

[7] M.F. Zawrah, E.M.A. Hamzawy, Effect of cristobalite formation on sinterability, microstructure and properties of glass/ceramic composites, Ceram. Int., 28 (2002) 123-130.

[8] M.M.R.A. Lima, R.C.C. Monteiro, M.P.F. Graça, M.G. Ferreira da Silva, Structural, electrical and thermal properties of borosilicate glass-alumina composites, J. Alloys Comp., 538 (2012) 66-72.

[9] K.A. Nielsen, M. Solvang, S.B.L. Nielsen, A.R. Dinesen, D. Beeaff, P.H. Larsen, Glass composite seals for SOFC application, J. Eur. Ceram. Soc., 27 (2007) 1817-1822.

[10] R.M.d. Nascimento, A.E. Martinelli, A.J.A. Buschinelli, Review Article: recent advances in metal-ceramic brazing, Cerâmica, 49 (2003) 178-198.

[11] M. Haydn, K. Ortner, T. Franco, S. Uhlenbruck, N.H. Menzler, D. Stöver, G. Bräuer, A. Venskutonis, L.S. Sigl, H.-P. Buchkremer, R. Vaßen, Multi-layer thinfilm electrolytes for metal supported solid oxide fuel cells, J. Power Sources, 256 (2014) 52-60.

[12] B. Timurkutluk, Y. Ciflik, H. Korkmaz, Strength evaluation of glass-ceramic composites containing yttria stabilized zirconia after thermal cycling, Ceram. Inter., 41 (2015) 6985-6990.

[13] K.S. Weil, The state-of-the-art in sealing technology for solid oxide fuel cells, JOM, 58 (2006) 37-44.

[14] F. Smeacetto, M. Salvo, M. Santarelli, P. Leone, G.A. Ortigoza-Villalba, A. Lanzini, L.C. Ajitdoss, M. Ferraris, Performance of a glass-ceramic sealant in a SOFC short stack, Int. J. Hydrogen Energ, 38 (2013) 588-596. 
[15] A. Durán, L. Pascual, M.J. Pascual, Vidrios y vitrocerámicos para soldadura: Usos tradicionales ynuevas áreas de aplicación, Bol. Soc. Esp. Ceram. Vidr., 36 (1997) 383-398.

[16] R.R. Tummala, Ceramic and Glass-Ceramic Packaging in the 1990s, J. Am. Ceram. Soc, 74 (1991) 895-908.

[17] R. Benavente, M.D. Salvador, O. García-Moreno, F.L. Peñaranda-Foix, J.M. Catalá-Civera, A. Borrell, Microwave, Spark Plasma and Conventional Sintering to Obtain Controlled Thermal Expansion $\beta$-Eucryptite Materials, Int. J. Appl. Ceram. Techn., 12 (2015) 1641-1648;

[18] R. Benavente, M.D. Salvador, A. Martínez-Amesti, A. Fernández, A. Borrell, Effect of sintering technology in $\beta$-eucryptite ceramics: Influence on fatigue life and effect of microcracks, Mater. Sci. Eng. A, 651 (2016) 668-674.

[19] P.L. Higby, J.E. Shelby, Properties of some simple glass/ceramic systems, J. Am. Ceram. Soc., 67 (1984) 445-449.

[20] W.D. Kingery, H.K. Bowen; D.R. Uhlmann. Introduction to ceramics, Jhon Willey \& Sons, New York. (1976).

[21] A.P.N. Oliveira, A.P. Barbieri, C. Leonelli, T. Manfredini, G.C. Pellacani, , L., Physical properties of quenched glasses in the $\mathrm{Li}_{2} \mathrm{O}-\mathrm{ZrO}_{2}-\mathrm{SiO}_{2}$ system, J. Am. Ceram. Soc., 79 (1996) 2 1092-1094.

[22] J. D.Teixeira, M. A. Pereira, L. Bohels, C. Siligardi, V. Cantavella, A.P.N. Oliveira, Physical-mechanical behaviour of a LZS glass-ceramic. Mater. Sci. Forum, 775-776 (2014) 5 599-603.

[24] S. Arcaro, F.R. Cesconeto, F. Raupp-Pereira, A.P.N. de Oliveira, Synthesis and characterization of $\mathrm{LZS} / \mathrm{\alpha}-\mathrm{Al}_{2} \mathrm{O}_{3}$ glass-ceramic composites for applications in the LTCC technology, Ceram. Int., 40 (2014) 5269-5274.

[25] C. Gomes, N. Travitzky, P. Greil, W. Acchar, H. Birol, A.P.N. de Oliveira, D. Hotza, Laminated object manufacturing of LZSA glass-ceramics, Rapid Prototyping Journal, 17 (2011) 424-428.

[26] A. P. N. Oliveira, T. Manfredini. $\mathrm{Al}_{2} \mathrm{O}_{3}$ Particulate-Reinforced LZS Glass Ceramic Matrix Composite 9th CIMTEC Word Ceram-ics Congress, Ceramics: Getting into the 2000's. GROUP, T. Faenza: (1998) 707-714..

[27] O.R.K. Montedo, F.J. Floriano, J..O. Filho, Sintering kinetics of a $18.8 \mathrm{Li}_{2} \mathrm{O}$ 8.3 $\mathrm{ZrO}_{2} 64.2 \mathrm{SiO}_{2} 8.7 \mathrm{Al}_{2} \mathrm{O}_{3}$ glass ceramic, Ceram. Int. 37 (2011) 1865-1871.

[28] O.R.K. Montedo, D. Hotza, A.P.N. de Oliveira, R. Meszaros, N. Travitzky, P. Greil, Crystallisation Kinetics of a -Spodumene-Based Glass Ceramic, Adv. Mater. Sci. Eng. 2012 (2012) 8.

[29] O.R.K. Montedo, F.M. Bertan, R. Piccoli, D. Hotza, A.N. Klein, A.P.N. de Oliveira, Low Thermal Expansion Sintered LZSA Glass-Ceramics, Am. Ceram Soc. Bull., 87 (2008) 34-40.

[30] S. Arcaro, M.I. Nieto, J.B. Rodrigues Neto, A.P.N. de Oliveira, R. Moreno, $\mathrm{Al}_{2} \mathrm{O}_{3}$ Nanoparticulate LZS glass-ceramic matrix composites for production of multilayered materials, J. Am. Ceram. Soc., (2016)

[31] S. Arcaro, M.I. Nieto, R. Moreno, A.P.N. de Oliveira, The influence of nano alumina additions on the coefficient of thermal expansion of a LZS glassceramic composition, Ceram. Int., 42 (2016) 8620-8626.

[32] S. Kemethmuller, A. Roosen, F. Goetz-Neunhoeffer, J. Neubauer, Quantitative analysis of crystalline and amorphous phases in glass-ceramic composites like LTCC by the rietveld method, J. Am. Ceram. Soc., 89 (2006) 2632-2637. 
[33] M. Sakata, M.J. Cooper, Analysis of the Rietveld Profile Refinement Method, J Appl Crystallogr, 12 (1979) 554-563.

[34] H.M. Rietveld, The Rietveld method, Phys Scripta, 89 (2014).

[35] K. Niihara, R. Morena, D. Hasselman, Evaluation of $\mathrm{K}_{\mathrm{IC}}$ of brittle solids by the indentation method with low crack-to-indent ratios, J. Mater. Sci. Lett., 1 (1982) 13-16.

[36] A.R. West, Solid State Chemistry and its Applications, John Wiley \& Sons, 2nd Edition, Student Edition, 2014, The Atrium, Southern Gate, Chichester, West Sussex, PO19 8SQ, United Kingdom.

[37] A.R. West, lonic conductivity of oxides based on $\mathrm{Li}_{4} \mathrm{SiO}_{4}, \mathrm{~J}$. Appl. Electrochem., 3 (1973) 327-335.

[38] R.B. Nuernberg, C.A. Faller, O.R.K. Montedo, Crystallization kinetics and thermal and electrical properties of $\beta$-spodumene/cordierite glass-ceramics $\mathrm{J}$. Therm. Anal. Calorim, (2016) 1-8.

[39] O.R.K. Montedo, I.T. Alves, C.A. Faller, F.M. Bertan, D.H. Piva, R.H. Piva, Evaluation of electrical properties of glass-ceramics obtained from mill scale, Mater. Res. Bull., 72 (2015) 90-97.

[40] R. Winter, K. Siegmund, P. Heitjans, Nuclear magnetic and conductivity relaxations by Li diffusion in glassy and crystalline LiAISi4O10, J. Non-Cryst. Solids, 212 (1997) 215-224.

[41] M.T. Sebastian, H. Jantunen, Low loss dielectric materials for LTCC applications: a review, Inter. Mater. Reviews, 53 (2008) 57-90.

[42] Y. Shi, X. Huang, D. Yan, Fabrication of hot-pressed zircon ceramics: Mechanical properties and microstructure, Ceram. Int., 23 (1997) 457-462.

[43] M. Awaad, H. Mörtel, S.M. Naga, Densification, mechanical and microstructure properties of $\beta$-spodumene-alumina composites, J. Mater. Sci: Mater. Electron., 16 (2005) 377-381.

[44] R. Benavente, M.D. Salvador, A. Martínez-Amesti, A. Fernández, A. Borrell, Effect of sintering technology in $\beta$-eucryptite ceramics: Influence on fatigue life and effect of microcracks. Mater. Sc. Eng. A, 651 (2016) 668-674.

[45] Z. Strnad, Glass-Ceramic Materials: Glass Science and Technology, Elsevier, New York, 1986.

[46] G.B.W. Holand, Glass-Ceramic Technology, The American Ceramic Society, Westerville, 2002.

[47] W. Martienssen, H. Warlimont, Springer handbook of condensed matter and materials data, Springer Science \& Business Media, 2006. 
Figure captions

Figure 1. SEM micrographs of fracture surfaces of the LZS glass-ceramic without (a) and with $1,2.5$, and 5 vol. $\% \mathrm{Al}_{2} \mathrm{O}_{3}$ (b, c, and d, respectively) after firing at $900 \stackrel{\circ}{\circ} / 30 \mathrm{~min}$.

Figure 2. X-ray diffraction patterns of the LZS glass-ceramic without (a) and with alumina additions of $1,2.5$, and 5 vol.\% $\mathrm{Al}_{2} \mathrm{O}_{3}$ (b, c, and $\mathrm{d}$, respectively) after firing at $900{ }^{\circ} \mathrm{C} / 30$ min. $\left(Z=Z_{r S i O} ; \mathrm{L}=\mathrm{Li}_{2} \mathrm{SiO}_{3} ; \mathrm{S}=\mathrm{LiAlSi}_{2} \mathrm{O}_{6} ; \mathrm{Q}=\mathrm{SiO}_{2}, \beta-\right.$ quartz; $\mathrm{D}=\mathrm{Li}_{2} \mathrm{Si}_{2} \mathrm{O}_{5}$.).

Figure 3. Nyquist diagram of the LZS glass-ceramic measured at a temperature of $500^{\circ} \mathrm{C}$.

Figure 4. Arrhenius plot (log of the electrical conductivity versus the inverse of temperature) for LZS glass-ceramic samples (without $\mathrm{Al}_{2} \mathrm{O}_{3}$ ) and for composites containing LZS $+1,2.5$ and 5 vol.\% of $\mathrm{Al}_{2} \mathrm{O}_{3}$ nanoparticles fired (sintering and crystallization) at $900 \stackrel{\circ}{\mathrm{C}}$ for $30 \mathrm{~min}$.

Figure 5. Thermal conductivity of LZS glass-ceramic samples (without $\mathrm{Al}_{2} \mathrm{O}_{3}$ ) and for the LZS $+\mathrm{Al}_{2} \mathrm{O}_{3}$ composites containing 1, 2.5 and 5 vol.\% of nanosized $\mathrm{Al}_{2} \mathrm{O}_{3}$ fired (sintering and crystallization) at $900 \stackrel{\circ}{\circ} \mathrm{C}$ for $30 \mathrm{~min}$. 
Figure 6. Vickers microhardness for LZS glass-ceramic samples (without $\mathrm{Al}_{2} \mathrm{O}_{3}$ ) and for $\mathrm{LZS}+\mathrm{Al}_{2} \mathrm{O}_{3}$ composites containing $1,2.5$ and 5 vol.\% of nanosized $\mathrm{Al}_{2} \mathrm{O}_{3}$ sintered fired (sintering and crystallization) at $900 \stackrel{\circ}{\mathrm{C}}$ for $30 \mathrm{~min}$

Figure 7. Young's modulus (E) for LZS glass-ceramic samples (without $\mathrm{Al}_{2} \mathrm{O}_{3}$ ) and for $\mathrm{LZS}+\mathrm{Al}_{2} \mathrm{O}_{3}$ composites containing 1, 2.5 and 5 vol\% of nanosized $\mathrm{Al}_{2} \mathrm{O}_{3}$ fired at $900 \stackrel{\circ}{\mathrm{C}}$ for $30 \mathrm{~min}$.

Figure 8. Fracture toughness $\left(\mathrm{K}_{\mathrm{IC}}\right)$ for the LZS glass-ceramic (without $\mathrm{Al}_{2} \mathrm{O}_{3}$ ) and for the LZS $+\mathrm{Al}_{2} \mathrm{O}_{3}$ composites containing 1,2.5 and 5 vol.\% of nanosized $\mathrm{Al}_{2} \mathrm{O}_{3}$ fired at $900 \stackrel{\circ}{\mathrm{C}}$ for $30 \mathrm{~min}$. 
Table 1. Chemical composition of the LZS parent glass.

\begin{tabular}{ccc}
\hline \multirow{2}{*}{$\begin{array}{c}\text { Constituent } \\
\text { oxides }\end{array}$} & \multicolumn{2}{c}{ Composition (wt\%) } \\
\cline { 2 - 3 } & Theoretical $^{[20]}$ & Analyzed \\
\hline $\mathrm{Al}_{2} \mathrm{O}_{3}$ & --- & 0.95 \\
$\mathrm{CaO}$ & --- & 0.05 \\
$\mathrm{Fe}_{2} \mathrm{O}_{3}$ & --- & 0.05 \\
$\mathrm{Li}_{2} \mathrm{O}$ & 9.6 & 8.63 \\
$\mathrm{Na}_{2} \mathrm{O}$ & --- & 0.05 \\
$\mathrm{SiO}_{2}$ & 68.1 & 68.02 \\
$\mathrm{TiO}_{2}$ & --- & 0.05 \\
$\mathrm{ZrO}_{2}$ & 22.4 & 22.20 \\
\hline
\end{tabular}


Table 2. Relative densities and linear shrinkage of samples fired at $900{ }^{\circ} \mathrm{C}$ for $30 \mathrm{~min}$.

\begin{tabular}{c|cc}
\hline Materials & $\begin{array}{c}\text { Relative density } \\
\text { (\%TD) }\end{array}$ & $\begin{array}{c}\text { Linear shrinkage } \\
\text { (\%) }\end{array}$ \\
\hline LZS glass-ceramic & $98.2 \pm 0.5$ & $15.7 \pm 1.0$ \\
LZS-1An & $96.9 \pm 1.0$ & $14.9 \pm 0.5$ \\
LZS-2.5An & $95.6 \pm 0.5$ & $14.7 \pm 1.0$ \\
LZS-5An & $92.6 \pm 0.5$ & $12.3 \pm 0.5$ \\
\hline
\end{tabular}


Table 3. Relative amounts of crystalline phases (Rietveld refinement) for samples of the LZS glass-ceramic without and with different alumina additions fired (sintering and crystallization) at $900^{\circ} \mathrm{C} / 30 \mathrm{~min}$.

\begin{tabular}{|c|c|c|c|c|c|c|}
\hline \multirow[t]{2}{*}{$\begin{array}{l}\text { Crystalline } \\
\text { phase }\end{array}$} & \multirow[t]{2}{*}{$\begin{array}{l}\text { Chemical } \\
\text { formula }\end{array}$} & \multirow[t]{2}{*}{$\begin{array}{c}\text { Unit cell } \\
\text { parameters }(\AA)\end{array}$} & \multicolumn{4}{|c|}{$\begin{array}{c}\text { Relative amounts of crystalline } \\
\text { phases } \\
\text { (wt\%) }\end{array}$} \\
\hline & & & $\begin{array}{c}\text { LZS } \\
\text { glass- } \\
\text { ceramic }\end{array}$ & $1 \mathrm{An}$ & 2.5An & $5 \mathrm{Ar}$ \\
\hline $\begin{array}{l}\text { Zirconium } \\
\text { silicate } \\
\text { (ICSD 100248) }\end{array}$ & $\mathrm{ZrSiO}_{4}$ & $\begin{array}{l}a=6.601735 \\
b=6.601735 \\
c=5.972209\end{array}$ & 34.8 & 32.5 & 33.1 & 32.5 \\
\hline $\begin{array}{l}\text { Lithium disilicate } \\
\text { (ICSD 15414) }\end{array}$ & $\mathrm{Li}_{2} \mathrm{Si}_{2} \mathrm{O}_{5}$ & $\begin{array}{l}a=5 ., 834453 \\
b=14.61852 \\
c=4.783636\end{array}$ & 44.5 & 28.8 & 20.4 & 17 \\
\hline $\begin{array}{c}\beta \text {-Quartz } \\
\text { (ICSD 64980) }\end{array}$ & $\mathrm{SiO}_{2}$ & $\begin{array}{l}a=4.953144 \\
b=4.953144 \\
c=5.413822\end{array}$ & 20.7 & 20.7 & 20.5 & 18.4 \\
\hline $\begin{array}{l}\beta \text {-spodumene } \\
\text { (ICSD 14235) }\end{array}$ & $\mathrm{LiAlSi}_{2} \mathrm{O}_{6}$ & $\begin{array}{l}a=7.472661 \\
b=7.472661 \\
c=9.03564\end{array}$ & & 13.9 & 19.2 & 25.1 \\
\hline $\begin{array}{c}\text { Lithium } \\
\text { metasilicate } \\
\text { (ICSD 28192) }\end{array}$ & $\mathrm{Li}_{2} \mathrm{SiO}_{3}$ & $\begin{array}{l}a=9.402353 \\
b=5.391150 \\
c=4.684093\end{array}$ & - & 4.1 & 6.8 & 7 \\
\hline \multicolumn{3}{|c|}{ GOF (Goodness of fit) } & 2.42 & 3.55 & 3.16 & 2.29 \\
\hline
\end{tabular}




\section{ACCEPTED MANUSCRIPT}

Table 4. Dielectric constant and dielectric loss values for samples of LZS glassceramic (without $\mathrm{Al}_{2} \mathrm{O}_{3}$ addition) and for composites ( $\mathrm{LSS}+\mathrm{Al}_{2} \mathrm{O}_{3}$ ) containing 1 , 2.5 and 5 vol. $\%$ of nanosized $\mathrm{Al}_{2} \mathrm{O}_{3}$ fired at $900{ }^{\circ} \mathrm{C}$ for $30 \mathrm{~min}$.

\begin{tabular}{l|ll}
\hline Materials & $E(-)$ & $\tan \delta(-)$ \\
\hline LZS glass-ceramic & 5.34 & 0.04 \\
LZS-1An & 5.81 & 0.05 \\
LZS-2.5An & 6.03 & 0.10 \\
LZS-5An & 6.11 & 0.18 \\
\hline
\end{tabular}


Table 5. $\varepsilon$ and tan $\delta$ data from commercial systems [40].

\begin{tabular}{|c|c|c|c|}
\hline $\begin{array}{l}\text { Commercial } \\
\text { Systems }\end{array}$ & Composition & $E(-)$ & $\tan \delta(-)$ \\
\hline Kyocera G5 & $\begin{array}{l}\text { Borate Silicate Glass }+\mathrm{SiO}_{2}+ \\
\qquad \mathrm{Al}_{2} \mathrm{O}_{3}+\text { cordierite }\end{array}$ & $5.0-6.2$ & - \\
\hline $\begin{array}{l}\text { Kyocera GL } 560 \\
\text { Kyocera GL } 530\end{array}$ & Crystallized glass $+\mathrm{Al}_{2} \mathrm{O}_{3}$ & $\begin{array}{l}6.0 \\
4.9\end{array}$ & $\begin{array}{c}0.0017 \\
0.0006(2 \\
\mathrm{GHz})\end{array}$ \\
\hline Murata & $\mathrm{BaO}-\mathrm{B}_{2} \mathrm{O}_{3}-\mathrm{Al}_{2} \mathrm{O}_{3}-\mathrm{CaO}-\mathrm{SiO}_{2}$ & 6. 1 & 0.0007 \\
\hline
\end{tabular}



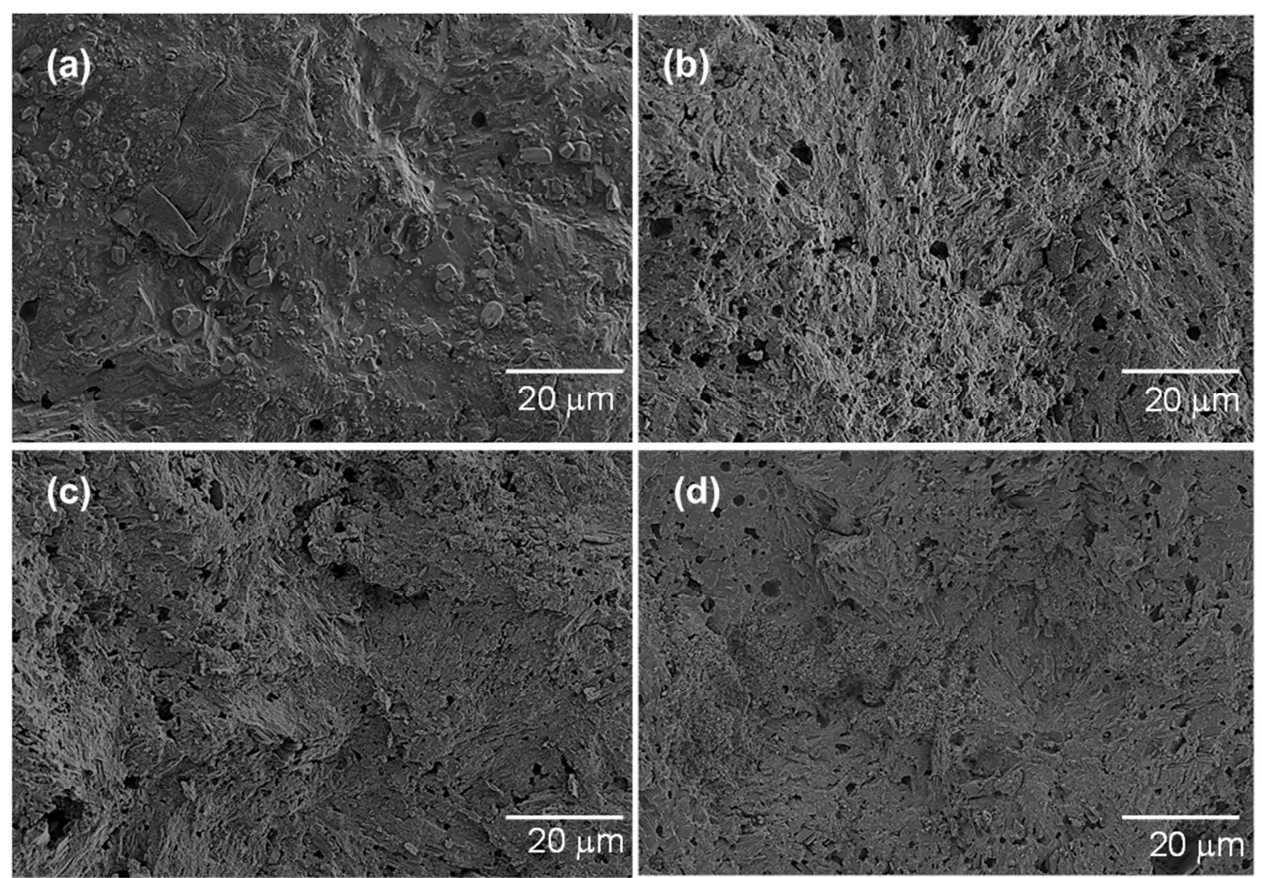

(d)

$20 \mu \mathrm{m}$ 


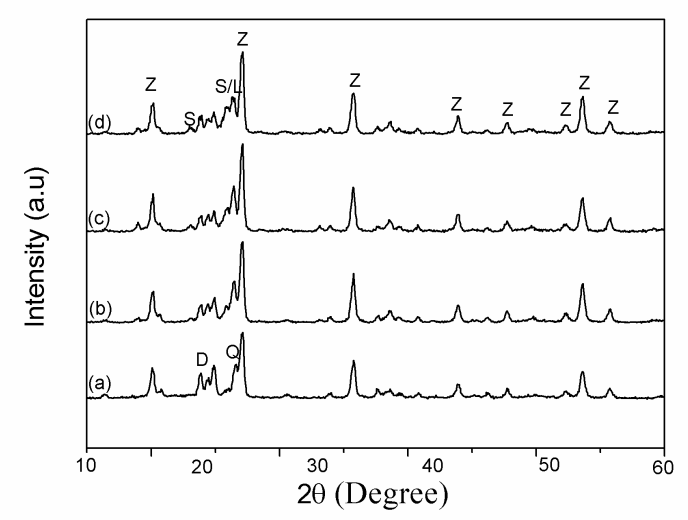




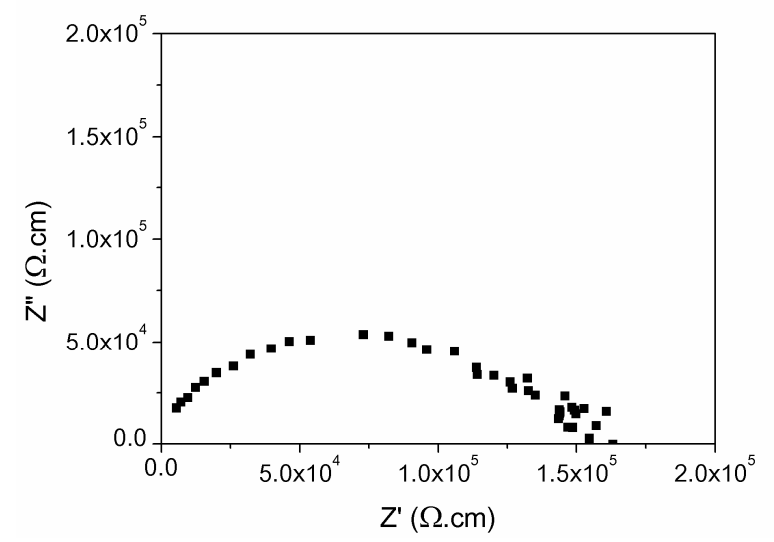




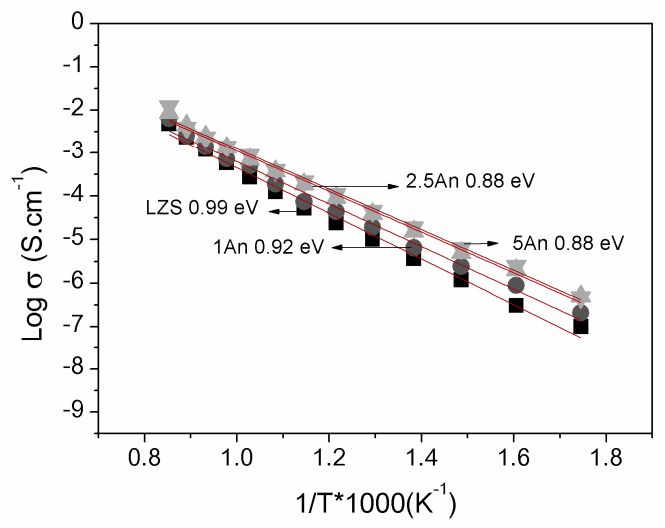




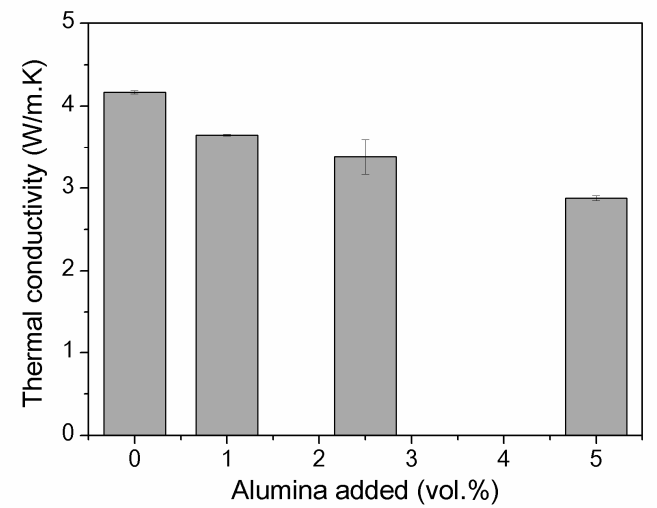




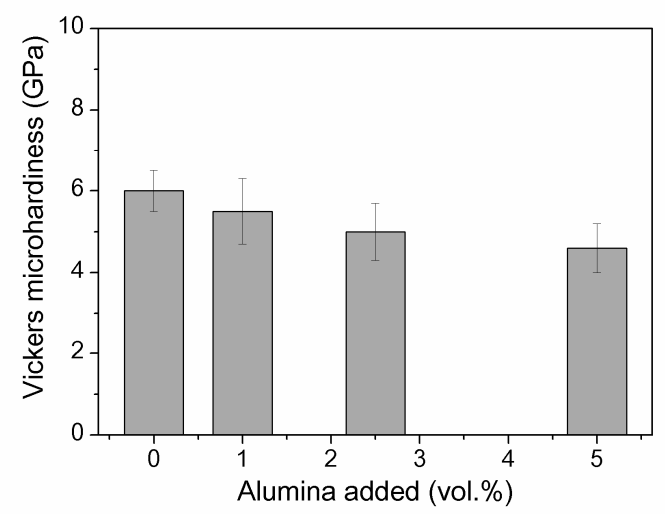




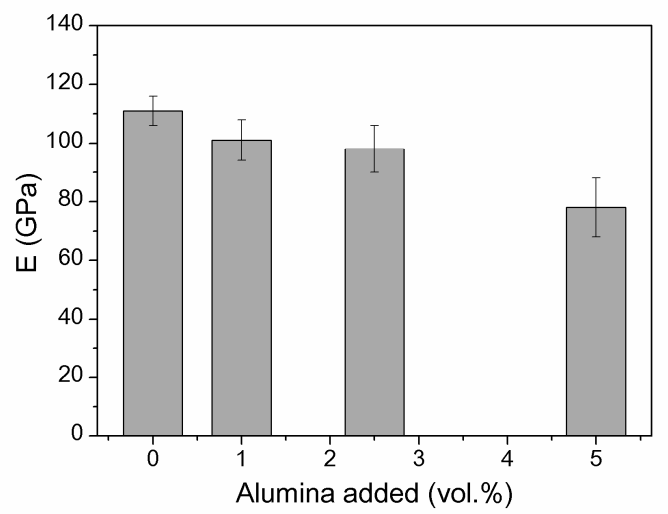




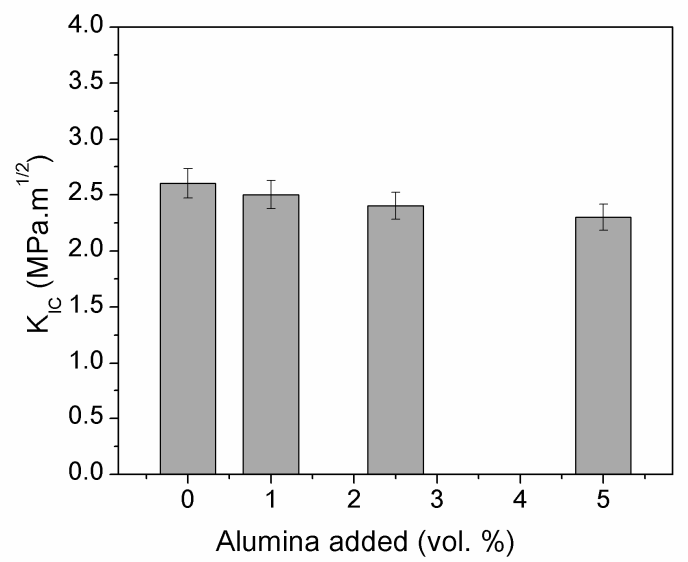


Highlights

LZS glass-ceramics and LZS $+\mathrm{Al}_{2} \mathrm{O}_{3}$ composites were successfully obtained.

Zirconium silicate and $\beta$-spodumene as the main formed crystalline phases.

Were obtained hardness of $6 \mathrm{GPa}$ and Young's modulus of $111 \mathrm{GPa}$ for LZS glassceramic.

The electrical conductivity of the composites was maintained within $\pm 10^{-7} \mathrm{~S} \cdot \mathrm{cm}^{-1}$ 